INDEPENDENT JOURNAL OF MANAGEMENT \& PRODUCTION (IJM\&P)

http://www.ijmp.jor.br

v. 11, n. 7, November - December 2020

ISSN: 2236-269X

DOI: 10.14807/ijmp.v11i7.1147

\title{
AN APPLICATION OF FUZZY ANALYTIC HIERARCHY PROCESS IN A UNIVERSITY TEACHING HOSPITAL
}

\author{
Mariana Izelli Miranda \\ State University of Maringá (UEM), Brazil \\ E-mail: mariana.izelli@gmail.com \\ Danilo Hisano Barbosa \\ State University of Maringá (UEM), Brazil \\ E-mail: dhbarbosa@uem.br \\ Syntia Lemos Cotrim \\ State University of Maringá (UEM), Brazil \\ E-mail: syntialceng@gmail.com \\ Submission: 10/18/2019 \\ Revision: $12 / 17 / 2019$ \\ Accept: 1/30/2020
}

\section{ABSTRACT}

Supplier's management plays an important role in cost and quality performance of purchasing companies. This important role has provided the growth of studies on the application of multi-criteria analysis method in manufacturing companies, although, with less impact on the services sector, mainly in the healthcare sector. For that reason, this research aimed to show the results of Fuzzy AHP multicriteria analysis method application in a university teaching hospital, with the purpose of improving the operation and internal management of pharmacy suppliers. Among the main results and contributions of the research, it is an elaborated description of each step of the method, followed by contextualization of the sector, revealing the application of fuzzy inference in the analysis of variables mostly qualitative in this specific sector. The findings of this study can provide the managers with valuable insights into the dimensions that reflect decision making when choosing suppliers in the setting of a university teaching hospital. By knowing these criteria, hospitals can increase their quality of service by selecting the best supply options for medical and hospital supplies, providing better service to patients.

Keywords: multi-criteria decision-making; analytic hierarchy process, fuzzy logic; university teaching hospital 
DOI: 10.14807/ijmp.v11i7.1147

\section{INTRODUCTION}

Decision-making is part of the human development process. The information received from the surroundings is necessary in order to obtain a good result. Due to the need of considering several factors, the purchasing decisions should not be made in isolation, thus, it is more appropriate to structure them in a sequence of interrelated steps in order to incorporate the organization needs in different areas (LIMA JUNIOR, 2013).

In the field of exact sciences, in decision-making perspective, there are mathematical models of linear programming for problem solutions. One of them is the multi-criteria decision support method, characterized by solving problems in which criteria are conflicting and judgments are subjective (GOMES; GOMES, 2012).

For the industry, one of the main decision-makings refers to supplier selection through predetermined criteria, mainly based on the developed product: any decision making influences directly the cost, the quality of the final product and the performance of the manufacturing organization (SAATY, 2008). The problem in the supplier selection process is the excessive use of time that the corporate team devotes to this action, resulting in lack of time to develop other activities (KEISLER, 2004).

In order to find a solution to the problem stated, there are some strategies of decision making such as the specific methods: one of them is the multi-criteria decision support method, which is characterized, according to (GOMES; GOMES, 2012), by solving problems in which criteria are conflicting and judgments are subjective. Thus, the service sector can benefit from these methods, although, there are few studies attesting it.

The main study found was done by (BRIOZO; MUSETTI, 2015), which highlights the several benefits not only in public management inside a social context but also in the private sector, improving profit, quality and time of service internally performed. This process was perceived through systematic observations executed at the university teaching hospital. It was identified that the only criterion used is the bidding process, in which only the value is relevant to choose the service provider.

Therefore, this paper aims to use the Fuzzy AHP method for supplier selection, with the purpose of improving the decision-making process in hospital services through management tool reducing social cost in public sectors, or increasing profit in private sectors, and reducing the risks resulting from a wrong decision concerning definition of location. It is important to emphasize that multi-criteria decision-making methods arose as a way of support 
DOI: 10.14807/ijmp.v11i7.1147

and they are known as effective mathematical tools for solving problems with conflicting criteria (BRANS; MARESCHAL, 2005).

These problems are common in Logistics and Supply Chain Management, more specifically in supplier selection process. According to (LIMA JUNIOR, 2013), this process can be determined as a decision problem in which several criteria must be considered while choosing possible supplier companies.

The central idea of AHP methodology is to transform a complex problem into minor and easier problems to solve, and thus support the decisions indicating the importance of each criterion, sub criteria and available alternatives. All of them are displayed hierarchically, in which the main problem is on the top and the alternatives are located at the bottom. The authors affirm that the technique is based on the transformation of pairwise judgments in numbers, referred as weights. Thereby, a weight is assigned for each item in the hierarchical tree considering the opinions of experts and judges (SCHMIDT; BARBOSA, 2016).

In spite of the efficiency, the method shows some uncertainties in the analysis process, because of the subjective aspects. Only the matrix of values consistency is evaluated in pairwise judgments, without considering any evaluation of noise involved in the initial values presented (SCHMIDT; BARBOSA, 2016). Hence, the Fuzzy logic is added to the AHP methodology in order to reduce the mistakes caused regarding the impreciseness of pairwise judgments, and thus present the results more accurately.

González-Benito (2007) emphasizes how professionals involved with supplies, the object of this study, easily understand the ground rules of the fuzzy system. That there are few studies using fuzzy logic in the management of different segments of the supplier base, as stated by (OSIRO, 2013).

This work importance is due to the few studies related to this methodology application in the service sector which, according to (MEIRELLES, 2006), one of the main characteristics is the intensive use of human resources, based on manual skills, information, and knowledge.

The problem was built focusing on the Teaching Hospital because there was no theorybased method for finding the best suppliers for the hospital.

Currently, the selection of suppliers is made through biddings, in which experts certify the quality of the product. In addition, the suppliers must comply with a number of requirements imposed by the State and at the end, if all the requirements are accomplished, such as quality test and best price; they win the race and have the opportunity to supply products 
DOI: 10.14807/ijmp.v11i7.1147

to the hospital. Those who do not meet the deadline and comply with the prior agreements receive sanctions or leave the hospital.

Inside the hospital, there are three big purchasing departments: pharmacy, nutrition, and warehouse. This research focus on the pharmacy department, more specifically, on the purchase of products used in surgery, disposable or not.

The main purpose of this research is to analyze and classify the suppliers of a university teaching hospital using the Fuzzy Analytic Hierarchy Process (FAHP) method by defining the most relevant criteria in the analysis and selection of suppliers. The research is based on the literature and with experts in the sector; the suppliers in question using the company portfolio; and structuring the problem using the principles of multi-criteria decision making (MCDM) support method.

\section{THEORETICAL BACKGROUND}

\subsection{Multi-Criteria Decision Making (MCDM) support method}

As previously mentioned, the process of decision-making implies numerous factors, which are difficult due to uncertainties of the process. Hillier and Lieberman (2013) suggest that this occurs, because decisions are rarely made in an environment where there is certainty of the factors. Problems like these are common in Logistic and Supply Chain Management, more specifically in supplier selection process. According to Lima Junior (2013), this process can be seen as a decision problem, in which several criteria have to be considered in judgment and selection of possible suppliers.

Therefore, the multi-criteria decision-making method arises as a way to help in the uncertainties produced during the process. They are mathematical tools, which help in conflicting criteria (BRANS; MARESCHAL, 2005). It is characterized as a discreet way of structuring problems, which involves several criteria or points of view, besides treating qualitative criteria or subjective evaluations (GOMES; GOMES, 2012).

In more detail, the multi-criteria method can be divided into multi-attribute decisionmaking (MADM) and multi-objective decision-making (MODM). The first, and most known in the scientific field, works with a limited number of alternatives which are ranked according to criteria established in the study. The main methods used to solve problems with those characteristics are: Analytic Hierarchy Process (AHP), Network Process (ANP), Elimination et Choix Traduisant la Realité (ELECTRE), Preference Ranking Organization Method for 
DOI: 10.14807/ijmp.v11i7.1147

Enrichment of Evaluations (PROMETHEE), Technique for Order of Preference by Similarity to Ideal Solution (TOPSIS) and Fuzzy AHP (DE CARLOS, 2016).

\subsection{Analytic Hierarchy Process}

Developed by Saaty in the 1970, the AHP is still a reference for solving problems involving subjective criteria. The method proposes the decomposition and synthesis of relationships between criteria, and thus it prioritizes the indicators and comes close to a better answer for their performance (SAATY, 2008). The method development follows the steps below (SAATY, 2008):

(i) Define the problem and the kind of knowledge to be explored;

(ii) Create the hierarchical tree: the proposed problem must structure a hierarchy, in order to visualize it in terms of goals, criteria, and alternatives. Therefore, the goal is at the top, followed by criteria and sub criteria at the intermediate level, and the alternatives are at the bottom.

(iii) Construct a pairwise comparison matrix; in this step, it is defined the alternatives weights in relation to the criteria, and the criteria in relation to the objectives, using the scale proposed by (SAATY, 2008), as shown in Table 1.

Table 1: Verbal Scale

\begin{tabular}{cc}
\hline Verbal Scale & Corresponding value \\
\hline $\begin{array}{c}\text { A has the same } \\
\text { importance as B }\end{array}$ & 1 \\
\hline $\begin{array}{c}\text { A has moderate } \\
\text { importance on B } \\
\text { A has strong } \\
\text { importance on B }\end{array}$ & 3 \\
\hline $\begin{array}{c}\text { A has very strong } \\
\text { importance on B }\end{array}$ & 5 \\
\hline $\begin{array}{c}\text { A has extremely } \\
\text { importance on B } \\
\text { Intermediate } \\
\text { values }\end{array}$ & 9 \\
\hline Source: Osiro (2013)
\end{tabular}

(iv) Calculate the consistency through consistency index (CI), random consistency index (RI) and consistency ratio (CR), as shown in eq. (1) - (3), representing the matrix order:

$$
\begin{aligned}
& \mathrm{CI}=\frac{\lambda \max -n}{n-1} \\
& \mathrm{RI}=\frac{1.98(n-2)}{n} \\
& \mathrm{CR}=\frac{{ }^{n}}{R I}
\end{aligned}
$$


DOI: 10.14807/ijmp.v11i7.1147

According to Taha (2003), to consider a judgment consistent, the CR must have a score no higher than 0,1 or $10 \%$, if the value exceeds it is recommended to review the judgments.

\subsection{Fuzzy Analytic Hierarquic Process}

Lofti Asker Zadeh introduced fuzzy logic in scientific circles in 1965. Chang (1996) decided to apply the methodology to AHP as a way of adding to the method and minimize errors that may happen, mainly in terms of degree of judgments inaccuracy (LINHARES; GUSSEN; RIBAS, 2012). As stated by Shaw and Simões (1999), the logic simulates the human way of thinking and its ability to make decisions in imprecise environments, allowing it to deal with confusing problems. Kahraman (2008) explain a few reasons for using the method, and one of them is that using a range of values to make a judgment is more efficient than just using another value. In addition, the authors emphasize that the logic minimizes the subjectivity and impreciseness of pairwise judgment.

The method, as in AHP, is based on criteria and alternatives of choice that must be independent of each other. The difference between methods is the triangulation of numbers, although the triangular method is more frequently used, there are others such as trapezoidal, gaussian, etc. The Fuzzy number determined is characterized by a membership function, which varies between the interval of $[0,1]$. Furthermore, the fuzzification degree is responsible for expressing the inaccuracy degree of judgment (LINHARES; GUSSEN; RIBAS, 2012).

The FAHP follows the steps, which are construct the hierarchical tree in the same way as the AHP Methodology; define linguistic variables and construct a triangular fuzzy number; perform a pairwise comparison between the criteria and the suppliers based on the criteria [20].

Transform the triangular number into a single crisp number and verify its consistency, as in the AHP method, through equations 4 and 5:

$$
\begin{aligned}
& \text { Mcrisp }=\frac{(4+1+m+n)}{6} \\
& \text { CI }=\frac{x-n}{\ln -1) * R I}
\end{aligned}
$$

Parameterize the matrices obtained, relate their weights, and define the best option among the alternatives for the objective previously mentioned. Therefore, FAHP allows transforming process uncertainties into mathematical values, reducing subjectivity in the decision process and the tendency of the judges, showing consistent results (LIMA JUNIOR, 2013). 
DOI: 10.14807/ijmp.v11i7.1147

\subsection{Supplier Selection}

When selecting a supplier two questions should be answered. The first one is whether the supplier has the ability to meet company requirements short and long term. The second refers to the supplier motivation to meet the expected requirements because without motivation there is no good relationship with the company (LEENDERS, 1997).

In Brazil, public companies select suppliers through a bidding process, as established by Law 8.666/93 (altered by Laws 8.883/94 and 9.648/98). However, in private companies, the selection is made according to the needs and reality of the companies.

Supplier selection arise from the company's need to subcontract the necessary supply or services. The element to be analyzed is the transaction cost in relation to suppliers. Thus, the process is improved when suppliers have the necessary characteristics to build a partnership, allowing the reduction of transaction costs (PERUCIA; BALESTRIN; VERSCHOORE, 2011).

Three processes are necessary to define the suppliers: selection and evaluation of suppliers, which are very close processes, and their development. The selection deals with relationship requirements established for the purchasing company, in this way, it is connected with the second process, the evaluation, which is the maintenance of their relationship. The purchasing company relates the third topic, supplier development, to supplier maintenance introduction, which should contain information intended for all readers of the journal, not just for specialists. It should describe the problem statement, its relevance, significant results and conclusions from prior works and the objectives of the work described in the manuscript submitted (FURTADO, 2005).

\section{MATERIALS AND METHODS}

\subsection{Research Methodology}

This study is classified as exploratory research, which aims to make the problems more familiar, making it more explicit through interviews with people who have practical knowledge of the problem; therefore, it assumes the case study format. This study follows the research method summarized in Figure 1: 
DOI: 10.14807/ijmp.v11i7.1147

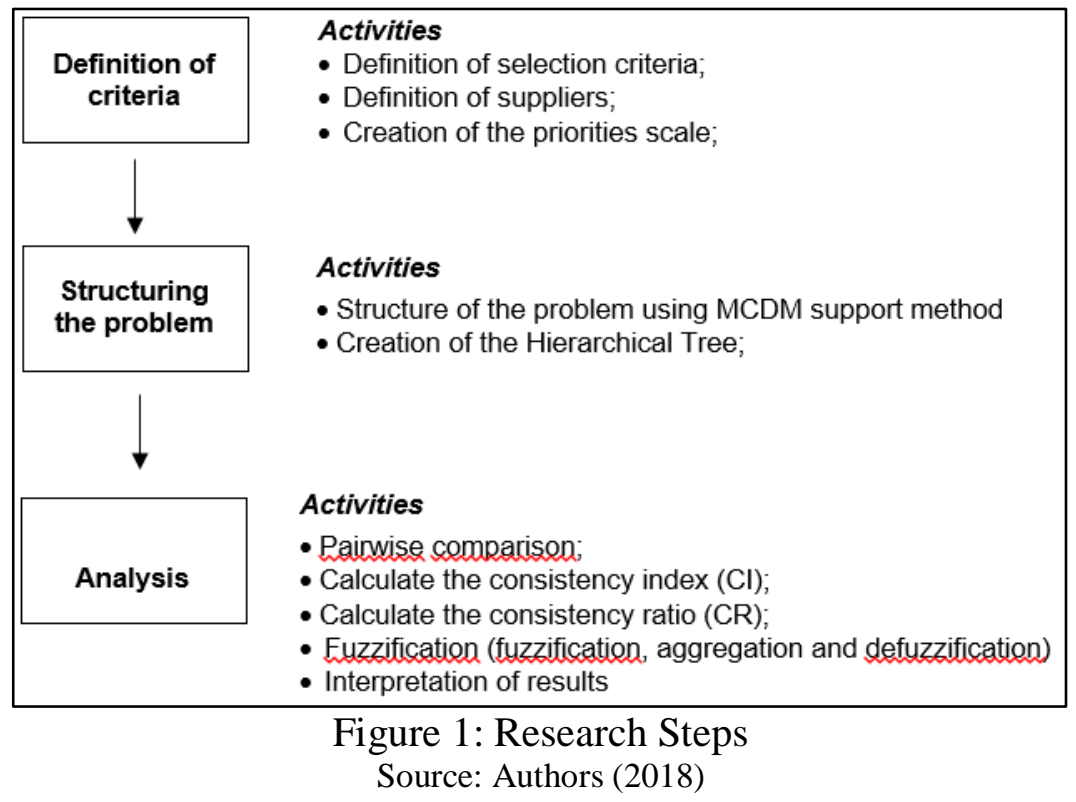

In general, in Figure 1 there are three macro-phases to execute the FAHP method. Firstly, there was the definition of the most relevant criteria in the analysis and the selection of suppliers, following the methodological assumptions indicated by the specialized literature and experts of the teaching hospital. After that, the suppliers were selected using the hospital portfolio. Next, the problem was structured using the principals of multi-criteria decisionmaking (MCDM) support method; finally, the results obtained with the implementation of the FAHP model were analyzed.

The detailed description of the method steps and the application results can be seen in section 4 .

\section{APPLICATION OF FAHP MODEL}

The process of development and application of the FAHP method was based on (DE CARLOS, 2016). The application was executed in the pharmacy department of a teaching hospital.

The FAHP method can be considered an improved form of AHP, and therefore, the first steps can be considered identical, only differing in judgment. As previously mentioned, the AHP tends to hierarchize the main problem, dividing it into decision criteria. At the beginning of decision-making process, using the AHP method, it is necessary to organize and determine priorities. Thus, for decision-making, it is required to define the problem, which in this study, the main issue aimed to find the best suppliers in the pharmacy sector at the teaching hospital. Next, it is required to determine the type of knowledge requested, structure the hierarchical tree in which the problem must be on the top, followed by criteria. 
ISSN: $2236-269 X$

DOI: 10.14807/ijmp.v11i7.1147

The criteria were selected by a group of experts in the supplies purchasing department in the pharmacy of the TH, as shown in Table 2.

Table 2: Criteria used in the problem

\begin{tabular}{c|c|c}
\hline Criteria & Description \\
\hline Acceptance & 1 & $\begin{array}{c}\text { The acceptance of hospital employees } \\
\text { who use the products }\end{array}$ \\
\hline Delivery compliance & 2 & $\begin{array}{c}\text { The product delivered is the same as } \\
\text { what was requested }\end{array}$ \\
\hline Cycle Time & 3 & Lead time between order and delivery \\
\hline Cost & C4 & Cost per batch of products \\
\hline
\end{tabular}

Source: Author (2018)

For ethical issues, the suppliers' names or alternatives will not be revealed, they will be referred as supplier 1 to supplier 7 .

Table 3: Suppliers for the analysis

\begin{tabular}{l|l}
\hline \multicolumn{2}{l}{ Suppliers } \\
\hline Supplier 1 & Hospital Products in Curitiba/PR \\
\hline Supplier 2 & Hospital Materials in Londrina/PR \\
\hline Supplier 3 & Hospital Surgical Products in Londrina/PR \\
\hline Supplier 4 & Hospital Medical Products in Curitiba/PR \\
\hline Supplier 5 & Medicines in Maringá/PR \\
\hline Supplier 6 & Medicines in Maringá/PR \\
\hline Supplier 7 & Hospital Supplies in Maringá/PR \\
\hline
\end{tabular}

Figure 2 illustrates the decision tree for the analysis, in which the hierarchical structure represents the goal (higher level), followed by the criteria at the intermediate level and the alternatives available at the bottom level.

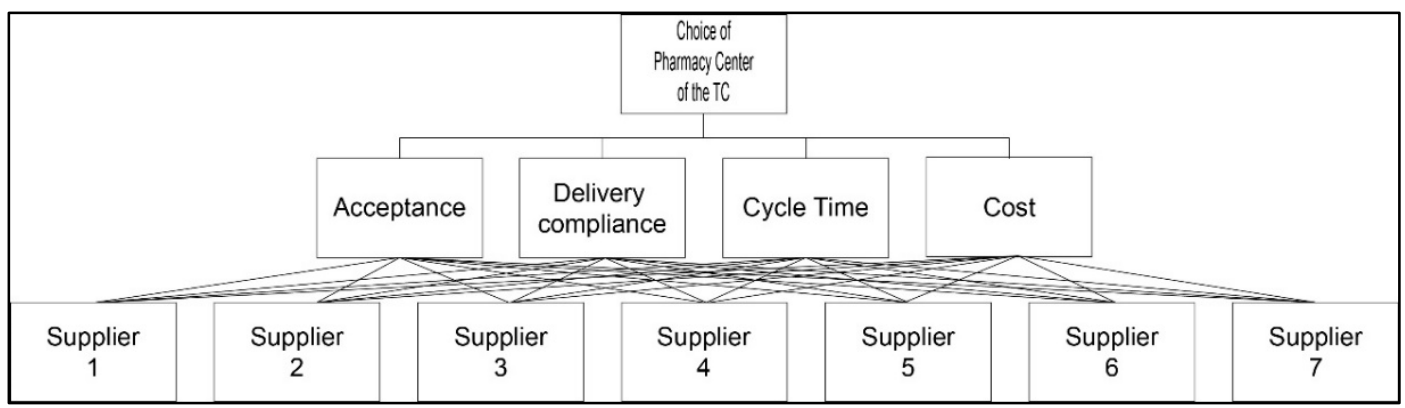

Figure 2: Hierarchical Tree

Source: Author (2018)

With the hierarchical tree organized, it is possible to visualize all the points of the processes and their connections.

\subsection{Definition of the linguistic variable}

The linguistic variable is used not only for criteria judgment, but also for supplier's judgment, considering each criterion. It is usual that in pairwise judgment, the judges use the 
DOI: 10.14807/ijmp.v11i7.1147

numerical values established by (SAATY, 2008), Table 1. In order to make the process easier, the method suggested by De Carlos (2016) was used, which intends to help the work of the judges, reduce doubts and minimize errors. Therefore, the priorities scale was replaced by the variables in Table 4, so that the person responsible for the judgment just need to mark with an " $x$ " among the available options, instead of putting numerical values, as suggested in the original model

Table 4: Scale for pairwise comparison

\begin{tabular}{|c|c|}
\hline \multicolumn{2}{|c|}{ Scale } \\
\hline I & A has equal importance as B \\
\hline IM & A has moderate importance over B \\
\hline IF & A has strong importance over B \\
\hline IMF & A has very strong importance over B \\
\hline IE & A has extreme importance over B \\
\hline $1 / \mathrm{IM}$ & B has moderate importance over A \\
\hline 1/IF & B has strong importance over A \\
\hline IMF & B has very strong importance over A \\
\hline 1/IE & B has extreme importance over A \\
& Source: Adapted from De Carlos (2016)
\end{tabular}

The judgment must be done as follows: among options A and B, what is the importance of criterion A in relation to criterion B. It must be done the same way with all suppliers based on each criterion. Consequently, the linguistic variable is transformed into numerical values, following Table 5, to the next steps (consistency index calculation, fuzzification, aggregation and defuzzification).

Table 5: Numerical Scale

\begin{tabular}{c|c|c}
\hline \multicolumn{3}{c}{ Numerical Transformation Scale } \\
\hline Values & Abbreviation & Definition \\
\hline 1 & E & Equal Importance \\
\hline 3 & MI & Moderate importance \\
\hline 5 & SI & Strong Importance \\
\hline 7 & VSI & Very Strong Importance \\
\hline 9 & EI & Extreme importance \\
\hline \multicolumn{3}{c}{ Source: Adapted from De Carlos (2016) }
\end{tabular}

With the definition of numerical transformation scale, from the linguistic variables, it is possible to move to criteria and suppliers evaluation by selected experts.

\subsection{Conducting criteria and suppliers evaluations}

The next step is regarding the creation of pairwise comparison matrices and judgment of criteria in pairs and supplier's judgment, considering each criterion. As previously mentioned, the method created by Saaty (2008) was adapted and thus, the judges, with the researcher's help, only marked with an " $x$ ” the comparison they felt was most appropriate. 
First, by comparing the criteria in pairs and then by comparing suppliers based on each criterion, as shown in Table 6 and 7.

For this step, three experts in the field were selected, with experience in strategic points inside the Hospital (one in the purchasing department and two medical interns in the HUM), in order to have an overview of suppliers and to make the method more satisfactory. However, it was possible to analyze a flaw in the operating method of the hospital, since the three experts only had information about their own area and not of the whole hospital.

It is important to emphasize that, when dealing with a public bidding, suppliers selected must follow the same price range. For this reason, there was no change in the supplier's classification based on criterion 4 . Therefore, as an example, the judge must analyze, under the cycle time criterion, what is the relation of importance between criterion 1 and criterion 2, and thus, successively, marking with an " $x$ " the cell they judged most appropriate.

After this process, the linguistic variables are transformed into numerical values, as mentioned in 1.2 section, as shown in Table 6.

Table 6: Numerical transformation

\begin{tabular}{|c|c|c|c|c|c|c|c|c|c|c|}
\hline Critério & IE & IMF & IF & IM & I & $1 /$ IM & $1 /$ IF & 1/IMF & 1/IE & Critério \\
\hline Acceptance & & & & & & 0,33 & & & & Delivery compliance \\
\hline Acceptance & 9 & & & & & & & & & Cycle Time \\
\hline Acceptance & & & & & & & 0,2 & & & Cost \\
\hline Delivery compliance & & & & & 1 & & & & & Cycle Time \\
\hline Delivery compliance & & & & & 1 & & & & & Cost \\
\hline Cycle Time & & & & & 1 & & & & & Cost \\
\hline
\end{tabular}

Source: Authors (2018)

It is important to highlight that all the process is also performed with the suppliers, based on each criterion, as can be seen in Table 7. 
Table 7: Numerical transformation for suppliers

\begin{tabular}{|c|c|c|c|c|c|c|c|c|c|c|}
\hline \multicolumn{11}{|c|}{ judgment: Cycle Time } \\
\hline & IE & IMF & IF & IM & $\mathrm{I}$ & $1 / \mathrm{IM}$ & $1 /$ IF & 1/IMF & $1 / \mathrm{IE}$ & \\
\hline Supplier 1 & & & & & & 0,33 & & & & Supplier 2 \\
\hline Supplier 1 & & & & & & 0,33 & & & & Supplier 3 \\
\hline Supplier 1 & 9 & & & & & & & & & Supplier 4 \\
\hline Supplier 1 & 9 & & & & & & & & & Supplier 5 \\
\hline Supplier 1 & 9 & & & & & & & & & Supplier 6 \\
\hline Supplier 1 & 9 & & & & & & & & & Supplier 7 \\
\hline Supplier 2 & & & & & 1 & & & & & Supplier 3 \\
\hline Supplier 2 & 9 & & & & & & & & & Supplier 4 \\
\hline Supplier 2 & 9 & & & & & & & & & Supplier 5 \\
\hline Supplier 2 & 9 & & & & & & & & & Supplier 6 \\
\hline Supplier 2 & 9 & & & & & & & & & Supplier 7 \\
\hline Supplier 3 & 9 & & & & & & & & & Supplier 4 \\
\hline Supplier 3 & 9 & & & & & & & & & Supplier 5 \\
\hline Supplier 3 & 9 & & & & & & & & & Supplier 6 \\
\hline Supplier 3 & 9 & & & & & & & & & Supplier 7 \\
\hline Supplier 4 & & & & & & 0,33 & & & & Supplier 5 \\
\hline Supplier 4 & & & & & & 0,33 & & & & Supplier 6 \\
\hline Supplier 4 & & & 5 & & & & & & & Supplier 7 \\
\hline Supplier 5 & & & & & 1 & & & & & Supplier 6 \\
\hline Supplier 5 & & & & 3 & & & & & & Supplier 7 \\
\hline Supplier 6 & & & 5 & & & & & & & Supplier 7 \\
\hline
\end{tabular}

The following step was to calculate the consistency index (CI) and the consistency ratio (CR), through equations 1,2 and 3 . The matrix is made from the calculation of the average values derived from the previous process, resulting in one matrix in relation to the criteria and four matrices in relation to the suppliers, as in Table 8.

Table 8: Comparison matrices

\begin{tabular}{|c|c|c|c|c|}
\hline Criteria & C1 & C2 & C3 & C4 \\
\hline C1 & 1 & 0,26 & 4,07 & 2,57 \\
\hline C2 & 3,85 & 1 & 4,33 & 5,67 \\
\hline C3 & 1,00 & 0,23 & 1 & 3,66 \\
\hline C4 & 0,39 & 0,176367 & 0,273224 & 1 \\
\hline Total & 6,235259 & 1,667314 & 9,673224 & 12,9 \\
\hline \multicolumn{5}{|c|}{ Source: Authors (2018) } \\
\hline
\end{tabular}

Using the methodology of Souza et al. (2010) and Corsi (2017), with the support of previous equations, the five matrices were built so that on the main diagonal was number 1 , above it the judgments average and below the main matrix, the inverse of the transposed. Thus, it is possible to verify the judgments consistency, registered in Table 9.

Table 9: CI and CR results

\begin{tabular}{|c|c|c|c|c|c|}
\cline { 2 - 6 } \multicolumn{1}{c|}{} & $\boldsymbol{\lambda} \boldsymbol{m a x}$ & $\boldsymbol{C I}$ & $\boldsymbol{n}$ & $\boldsymbol{R I}$ & $\boldsymbol{C R}$ \\
\hline Criteria & 4,88 & 0,29 & 4,00 & 1,98 & 0,1 \\
\hline Suppliers C1 & 8,79 & 0,30 & 7,00 & 1,41 & 0,1 \\
\hline Suppliers C2 & 7,47 & 0,08 & 7,00 & 1,41 & 0,06 \\
\hline Suppliers C3 & 7,68 & 0,01 & 7,00 & 1,41 & 0,08 \\
\hline Suppliers C4 & 7,00 & 0,00 & 7,00 & 1,41 & 0,00 \\
\hline
\end{tabular}

Source: Authors (2018) 
DOI: 10.14807/ijmp.v11i7.1147

In Table 9, it is possible to observe that all consistency ratio (CR) values are below the 0,1 or $10 \%$ limit, proving that the judgments are consistent and can be used in the next steps, following the methodological assumptions of Taha (2003) and Saaty (2008).

\subsection{Fuzzification Process}

After confirming the consistency of judgments, it is possible to start the fuzzy logic process creating the fuzzy number. It has a triangular shape composed by a vector with 3 points (Lij, Mij, Uij), obtained through the transformation of pairwise comparisons from the five matrices derived from the previous process (criteria and suppliers based on each criterion).

The $L_{i j}$ position is the minimum value obtained from the line in the judgment, $M_{i j}$ is the average and $U_{i j}$ is the maximum value found among them, as shown in Table 10 the triangulation of comparison matrix under the criteria.

Table 10: Triangular numbers

\begin{tabular}{|l|l|l|l|}
\cline { 2 - 4 } \multicolumn{1}{c|}{} & $\mathrm{L}$ & $\mathrm{m}$ & $\mathrm{U}$ \\
\hline $\mathrm{c} 1 \mathrm{c} 2$ & 0,14 & 0,26 & 0,33 \\
\hline $\mathrm{c} 1 \mathrm{c} 3$ & 0,2 & 4,07 & 9 \\
\hline $\mathrm{c} 1 \mathrm{c} 4$ & 0,2 & 2,57 & 7 \\
\hline c2c3 & 1 & 4,33 & 9 \\
\hline c2c4 & 1 & 5,67 & 9 \\
\hline c3c4 & 1 & 3,66 & 5 \\
\hline \multicolumn{4}{|c|}{ Source: Authors (2018) }
\end{tabular}

Besides triangulation between criteria, it is necessary to use it for suppliers based on each criterion, in this way it becomes possible to determine the weights assigned for each criterion.

\subsection{Aggregation}

After getting the triangular number, it is necessary to aggregate the values to reach a single number, which will be used in the following processes. It is necessary the creation of fuzzy matrices (criteria and suppliers based on each criterion), through FAHP algorithm.

For the matrix creation, each cell receives a vector of three values, the main diagonal has the values $(1,1,1)$, above it, there are the values corresponding to the concatenation, and below it, the transposed with the reverse of each triangular value, inverting the position of the extremities. 
ISSN: 2236-269X

DOI: 10.14807/ijmp.v11i7.1147

With the values obtained, it is possible to calculate the matrix for the criteria and the four matrices for the suppliers based on each criterion, as can be observed between Tables 11 and 12.

Table 11: Triangular matrix for criteria

\begin{tabular}{|c|c|c|c|c|}
\hline Criteria & C1 & C2 & C3 & C4 \\
\hline C1 & $(1,1,1)$ & $(0,14,0,26,0,33)$ & $(0,2,4,07,9)$ & $(0,2,2,57,9)$ \\
\hline C2 & $(3,03,3,84,7,14)$ & $(1,1,1)$ & $(1,4,33,9)$ & $(1,5,67,9)$ \\
\hline C3 & $(0,11,0,2,5)$ & $(0,11,0,23,1)$ & $(1,1,1)$ & $(1,3,66,5)$ \\
\hline C4 & $(0,14,0,38,5)$ & $(0,11,0,17,1)$ & $(0,2,0,27,1)$ & $(1,1,1)$ \\
\hline
\end{tabular}

Source: Authors (2018)

Table 12: Suppliers triangular matrix

\begin{tabular}{|c|c|c|c|c|c|c|c|}
\hline Aceitação & $F 1$ & $F 2$ & $F 3$ & $F 4$ & $F 5$ & $F 6$ & $F 7$ \\
\hline F1 & $(1,1,1)$ & $(1,3,66,5)$ & $(1,3,67,5)$ & $(5,5,5)$ & $(1,3,67,5)$ & $(1,3,67,5)$ & $(5,4,33,3)$ \\
\hline F2 & $(0,2,0,27,1)$ & $(1,1,1)$ & $(7,4,67,7)$ & $(1,5,7)$ & $(7,7,7)$ & $(1,5,7)$ & $(1,5,7)$ \\
\hline F3 & $(0,2,0,27,1)$ & $(0,14,0,21,0,14)$ & $(1,1,1)$ & $(7,8,33,9)$ & $(1,6,33,9)$ & $(1,6,33,9)$ & $(1,6,33,9)$ \\
\hline$F 4$ & $(0,2,0,2,0,2)$ & $(0,14,0,2,1)$ & $(0,11,0,12,0,14)$ & $(1,1,1)$ & $(0,33,0,33,0,33)$ & $(0,33,0,33,0,33)$ & $(0,33,0,33,0,33)$ \\
\hline F5 & $(0,2,0,27,1)$ & $(0,14,0,14,0,14)$ & $(0,11,0,16,1)$ & $(3,03,3,03,3,03)$ & $(1,1,1)$ & $(1,1,1)$ & $(1,1,1)$ \\
\hline F6 & $(0,2,0,27,1)$ & $(0,14,0,2,1)$ & $(0,11,0,16,1)$ & $(3,03,3,03,3,03)$ & $(1,1,1)$ & $(1,1,1)$ & $(1,2,33,3)$ \\
\hline F7 & $(0,2,0,23,0,33)$ & $(0,14,0,2,1)$ & $(0,11,0,16,1)$ & $(3,03,3,03,3,03)$ & $(1,1,1)$ & $(0,33,0,43,1)$ & $(1,1,1)$ \\
\hline
\end{tabular}

Source: Authors (2018)

Finally, it is necessary to reduce the matrices to a single fuzzy triangular number through the geometric mean of the corresponding vectors of the aggregation vector. Consequently, the first position of the resulting vector will be the geometric mean of the first positions of the fuzzy numbers corresponding to the matrix line, as shown in Figure 3, and the sum line will be the resulting sum of each column. The result can be observed in Table 13 .

$$
l_{i j}=\left(\prod_{k=1}^{K} l_{i j k}\right)^{\frac{1}{K}}, \quad m_{i j}=\left(\prod_{k=1}^{K} m_{i j k}\right)^{\frac{1}{K}}, u_{i j}=\left(\prod_{k=1}^{K} u_{i j k}\right)^{\frac{1}{K}}
$$

Figure 3: Aggregation equations

Source: De Carlos (2016)

Table 13: Aggregation

\begin{tabular}{|l|l|l|l|}
\cline { 2 - 4 } \multicolumn{1}{c|}{} & $\mathrm{L}$ & $\mathrm{m}$ & $\mathrm{U}$ \\
\hline $\mathrm{C} 1$ & 1,00 & 2,58 & 3,35 \\
\hline $\mathrm{C} 2$ & 1,09 & 2,87 & 3,80 \\
\hline C3 & 1,18 & 2,89 & 3,75 \\
\hline C4 & 1,18 & 2,73 & 3,44 \\
\hline Total & 4,45 & 11,07 & 14,34 \\
\hline \multicolumn{4}{|c|}{ Source: Authors (2018) }
\end{tabular}

After the aggregation process, the criteria and the suppliers have a singular triangular number, consisting of the vectors $\mathrm{L}, \mathrm{m}$ and $\mathrm{U}$, which allows it to go to the last stage of the process. 
ISSN: $2236-269 X$

DOI: 10.14807/ijmp.v11i7.1147

\subsection{Defuzzification and parameterization of comparison matrices}

After the aggregation process, it is required the defuzzification of values obtained in order to achieve the weights of each criterion and supplier, and thus, rank the selection of suppliers. The first step of the process is to divide each value $(\mathrm{l}, \mathrm{m}, \mathrm{u})$ by the sum of corresponding values, as shown in Figure 4. The defuzzification comes in the next step, in which the weights are determined - crip (criteria priorities), through the arithmetic mean of weight vectors.

$$
l_{\text {peso }}^{i}=\frac{l_{i}}{l_{\text {soma }}}, \quad m_{\text {peso }}^{i}=\frac{m_{i}}{m_{\text {soma }}}, \quad u_{\text {peso }}^{i}=\frac{u_{i}}{u_{\text {soma }}}, \quad i=1, \ldots, 7
$$

Figure 4: Equation for the defuzzification process Source: De Carlos (2016)

Table 14: Aggregation, defuzzification and criteria weights

\begin{tabular}{|c|c|c|c|c|c|c|c|}
\hline \multicolumn{4}{|c|}{ Aggregation } & \multicolumn{3}{|c|}{ Weight -Fuzzy } & \multirow{2}{*}{$\begin{array}{l}\text { Weights } \\
\text {-Crisp }\end{array}$} \\
\hline & I & $\mathrm{m}$ & $\mathrm{u}$ & I & $\mathrm{m}$ & $\mathrm{u}$ & \\
\hline C1 & 1,00 & 2,58 & 3,21 & 0,23 & 0,23 & 0,23 & 0,231 \\
\hline $\mathrm{C} 2$ & 1,09 & 2,87 & 3,64 & 0,25 & 0,26 & 0,27 & 0,257 \\
\hline C3 & 1,18 & 2,89 & 3,59 & 0,26 & 0,26 & 0,26 & 0,262 \\
\hline $\mathrm{C} 4$ & 1,18 & 2,73 & 3,28 & 0,26 & 0,25 & 0,24 & 0,250 \\
\hline Total & 4,45 & 11,07 & 13,72 & 1 & 1 & 1 & 1 \\
\hline
\end{tabular}

Source: Authors (2018)

In the same way that the defuzzification process was performed for the criteria, it is necessary to obtain the suppliers’ weights based on each criterion, as in Table 15.

Table 15: Suppliers' weights regarding each criterion

\begin{tabular}{|ll|l|l|l|}
\cline { 2 - 5 } \multicolumn{1}{c|}{} & C1 & C2 & C3 & C4 \\
\hline F1 & 0,177 & 0,140 & 0,131 & 0,143 \\
\hline F2 & 0,224 & 0,140 & 0,144 & 0,143 \\
\hline F3 & 0,236 & 0,140 & 0,144 & 0,143 \\
\hline F4 & 0,076 & 0,132 & 0,123 & 0,143 \\
\hline F5 & 0,096 & 0,132 & 0,129 & 0,143 \\
\hline F6 & 0,092 & 0,132 & 0,135 & 0,143 \\
\hline F7 & 0,099 & 0,184 & 0,195 & 0,143 \\
\hline TOTAL & 1 & 1 & 1 & 1 \\
\hline \multicolumn{5}{|c|}{ Source: Authors (2018) } \\
\hline
\end{tabular}

The next step was the obtainment of global weight, which will show the preferences in the analyzed case. In this step, it was required to calculate the product between the suppliers' weight and the analyzed criterion weight. In the case studied four tables were necessary, as shown in Table 16 relative to criterion 1 (Acceptance), which was repeated for all the criteria, changing only their weight. 
DOI: 10.14807/ijmp.v11i7.1147

Table 16: Values of the acceptance criteria for global weight

\begin{tabular}{|c|c|c|c|}
\hline \multicolumn{4}{|c|}{ Criterion: Acceptance } \\
\hline Supplier & Supplier Weight & $\begin{array}{c}\text { Criterion } \\
\text { Weight }\end{array}$ & Product \\
\hline F1 & 0,177 & 0,231 & 0,040902 \\
\hline F2 & 0,224 & 0,231 & 0,05178 \\
\hline F3 & 0,236 & 0,231 & 0,054498 \\
\hline F4 & 0,076 & 0,231 & 0,017467 \\
\hline F5 & 0,096 & 0,231 & 0,022083 \\
\hline F6 & 0,092 & 0,231 & 0,021277 \\
\hline F7 & 0,099 & 0,231 & 0,022846 \\
\hline \multicolumn{4}{|c|}{ Source: Authors (2018) } \\
\hline
\end{tabular}

With the creation of the four tables, the global weight is obtained for each supplier through the sum of the products derived from the previous step (product weight and criterion weight); the result can be analyzed through Table 17.

Table 17: Global Weight

\begin{tabular}{|l|c|}
\hline Supplier & $\begin{array}{c}\text { Global } \\
\text { Weight }\end{array}$ \\
\hline F1 & 0,147 \\
\hline F2 & 0,161 \\
\hline F3 & 0,164 \\
\hline F4 & 0,119 \\
\hline F5 & 0,125 \\
\hline F6 & 0,126 \\
\hline F7 & 0,157 \\
\hline
\end{tabular}

Source: Authors (2018)

After the defuzzification process, it was possible to analyze the data and classify them according to their weights.

\section{ANALYSIS OF RESULTS}

With all steps completed (definition of criteria, creation of the hierarchical tree, definition of the linguistic variable, calculation of consistency index, fuzzification, aggregation and defuzzification) it was possible to achieve the study objective, which consisted in evaluating the suppliers of a university hospital. In addition, to evaluate the criteria used and the suppliers based on each criterion.

The criteria were classified according to the weights obtained in the previous process and they can be seen through Table 18. It is possible to observe that there are no great deviations, due to the strict bidding process of the hospital, where all suppliers follow strict criteria to be approved. Another fact observed in Table 18 is that despite the low standard deviation, the cycle time was the most important criterion, 26,20\%, since in the interviews with 
experts it was pointed as a crucial criterion for the hospital, since it cannot make a large order of some items that may be essential in some cases. Therefore, it is necessary that the supplier's cycle time be as short as possible.

Table 18: Criteria Ranking

\begin{tabular}{|c|c|c|}
\hline \multicolumn{3}{|c|}{ Criteria } \\
\hline Ranking & Criteria & Weight \\
\hline $1^{\circ}$ & C3 - Cycle Time & 0,262 \\
\hline $2^{\circ}$ & C2 - Delivery compliance & 0,257 \\
\hline $3^{\circ}$ & C4 - Cost & 0,250 \\
\hline $4^{\circ}$ & C1 - Acceptance of Interns & 0,231 \\
\hline \multicolumn{2}{|r|}{ TOTAL } & 1 \\
\hline
\end{tabular}

The FAHP also enabled to classify the suppliers based on each criterion, as shown in Table 19. When analyzing each criterion individually, it was possible to visualize a great difference in global weight between suppliers of the acceptance and the cycle time criteria. Between suppliers and delivery compliance criterion, there is a great variation between the first position and the rest. Thus, the Supplier 7 has a big advantage based on the criterion.

It is important to emphasize that in the weight criterion all suppliers remain in the same position. This can be explained due to the result of the bidding process, in which all hospital suppliers present the lowest possible price in the market. Therefore, they are all similar in regarding this criterion, resulting in the same degree of classification.

Table 19: Ranking of suppliers based on the criteria

\begin{tabular}{|c|c|c|c|c|c|}
\hline \multicolumn{3}{|c|}{ Acceptance } & \multicolumn{3}{|c|}{ Cycle Time } \\
\hline Ranking & Supplier & $\begin{array}{l}\text { Global } \\
\text { Weight }\end{array}$ & Ranking & Supplier & $\begin{array}{l}\text { Global } \\
\text { Weight }\end{array}$ \\
\hline $1^{\circ}$ & F2 & 0,244 & $1^{\circ}$ & F7 & 0,195 \\
\hline $2^{\circ}$ & F3 & 0,236 & $2^{\circ}$ & F2 & 0,144 \\
\hline $3^{\circ}$ & F1 & 0,177 & $2^{\circ}$ & F3 & 0,144 \\
\hline $4^{\circ}$ & F7 & 0,099 & $3^{\circ}$ & F6 & 0,135 \\
\hline $5^{\circ}$ & F5 & 0,096 & $4^{\circ}$ & F1 & 0,131 \\
\hline $6^{\circ}$ & F6 & 0,092 & $5^{\circ}$ & F5 & 0,129 \\
\hline $7^{\circ}$ & $\mathrm{F} 4$ & 0,076 & $6^{\circ}$ & $\mathrm{F} 4$ & 0,123 \\
\hline \multicolumn{3}{|c|}{ Delivery Compliance } & \multicolumn{3}{|l|}{ Cost } \\
\hline Ranking & Supplier & \begin{tabular}{|l|} 
Global \\
Weight
\end{tabular} & Ranking & Supplier & \begin{tabular}{|l|} 
Global \\
Weight
\end{tabular} \\
\hline $1^{\circ}$ & F7 & 0,184 & $1^{\circ}$ & F1 & 0,143 \\
\hline $2^{\circ}$ & F1 & 0,140 & $1^{\circ}$ & F2 & 0,143 \\
\hline $2^{\circ}$ & F2 & 0,140 & $1^{\circ}$ & F3 & 0,143 \\
\hline $2^{\circ}$ & F3 & 0,140 & $1^{\circ}$ & F4 & 0,143 \\
\hline $3^{\circ}$ & F4 & 0,132 & $1^{\circ}$ & F5 & 0,143 \\
\hline $3^{\circ}$ & F5 & 0,132 & $1^{\circ}$ & F6 & 0,143 \\
\hline $3^{\circ}$ & F6 & 0,132 & $1^{\circ}$ & F7 & 0,143 \\
\hline
\end{tabular}

Source: Authors (2018) 
DOI: 10.14807/ijmp.v11i7.1147

With the results shown in Table 19, it is possible to emphasize that some suppliers stand out between the first positions of the four criteria: Suppliers 2 and 3. However, some suppliers stand out on the negative side: Suppliers 4 and 5, reflecting the overall ranking of suppliers, which can be seen in Table 20.

Table 20: Suppliers ranking by FAHP method.

\begin{tabular}{|l|l|c|}
\hline \multicolumn{3}{|c|}{ Suppliers } \\
\hline Ranking & Supplier & $\begin{array}{c}\text { Global } \\
\text { Weight }\end{array}$ \\
\hline $1^{\circ}$ & F3 & 0,164 \\
\hline $2^{\circ}$ & F2 & 0,161 \\
\hline $3^{\circ}$ & F7 & 0,157 \\
\hline $4^{\circ}$ & F1 & 0,147 \\
\hline $5^{\circ}$ & F6 & 0,126 \\
\hline $6^{\circ}$ & F5 & 0,125 \\
\hline $7^{\circ}$ & F4 & 0,119 \\
\hline Total & & 1 \\
\hline \multicolumn{2}{|c|}{ Source: Authors (2018) } \\
\hline
\end{tabular}

Therefore, it is possible to point out the best suppliers of the hospital, attaining the main objective of this study. It is important to emphasize the difference between the first, $16,40 \%$ and the last position, $11,90 \%$, that might be considered a large difference since the hospital must seek excellence in its suppliers, so there was no abrupt variation between the first and last positions.

Büyüközkan, Çifçi and Güleryüz (2011) used the SERVQUAL methodology in an effort to measure service quality, in which the concept and factors of service quality were examined. Then, they used the Fuzzy AHP to evaluate the proposed quality of service structure. Among the main results obtained with the research is the development of a decision-making model that can assist in the assessment of the perceived quality of service in the health sector, in which hospitals must focus more on empathy, professionalism and reliability to provide a satisfactory and qualified service.

In another work Lin, $\mathrm{Wu}$ and Chen (2008) using the FAHP technique, obtained 6 criteria and 18 subcriteria to select a location to build a hospital through a questionnaire organized by 17 hospital managers. In a similar study conducted by Chatterjee and Mukherjee (2013) using the FAHP, they interviewed 12 experienced doctors in the field of hospital management and health care to select the best location for a hospital in India. It was determined that sub-factors such as land cost, population density, proximity to public transport and economic and market conditions played an important role in assessing location. 
DOI: 10.14807/ijmp.v11i7.1147

Another similar study was conducted by Soltani and Marandi (2011) in Iran, in which 4 criteria were considered: distance from main streets and health services, population density and land size. Decision-making took place in two stages and was used to determine the appropriate location, obtaining in the first three lands and, finally, a selected land (MEIRELLES, 2006).

There are other studies, such as Liberatore and Nydick (2008), which identified the use of AHP and not FAHP to assist decision-making in the assessment and selection of therapies and treatments and the assessment of health care technologies and policies.

The focus of the few existing studies using FAHP in the health sector is to choose the best location for hospital organizations. This method could be best used in all fields where managers must select from two or more options and classify them, such as selection of suppliers, causes of diseases and the choice of appropriate therapy, development of health facilities, among others. It seems that one of the most important obstacles to research is the lack of knowledge by health authorities on these methods and the limited use in some decisionmaking situations. Thus, we suggest expanding the scope of applications of the methodology in other situations of decision-making in the hospital environment.

\section{CONCLUSIONS}

Decision-making is the essence of management, which is a complex task for managers today, requiring substantial time for its execution. Currently, managing matters of organizations does not depend on the individual judgment of individuals, but on judgments based on scientific methods, detailed information and decision-making techniques, especially in sectors of a special issue such as health, where decision-making can have an impact in human life.

Another importance is that the one concerning the use of appropriate and accurate decision-making methods such as the FAHP, which can decrease the potential costs of wrong decisions. In addition to the powerful theoretical basis, decision-making with several criteria offers the possibility to formulate and review the problem and to consider different options with quantity and quality criteria and their integration and to consider the opinions of different individuals. Thus, this study aimed to explain the use of a tool, usually used in the industry, to service sector in order to improve performance and internal management of the place studied, the University Teaching Hospital, seeking to classify pharmacy sector suppliers. 
DOI: 10.14807/ijmp.v11i7.1147

The main problem found in the research development are related to hospital management, since several internal departments have great autonomy and there is no information management between them. This made more difficult to evaluate the suppliers and determine the criteria because each expert consulted (doctors, nurses, and head of the warehouse) knew only about their own area. This systemic and holistic view is sustained as advised practice in modern production management.

Another point to highlight is the lack of scientific studies to support the research, considering that there are few studies about the theme and almost no research about FAHP in the service sector. The fact of public hospitals in the Parana state use bidding to obtain their suppliers is also a limitation for the research, because through this criterion all suppliers are capable and have similar qualities.

This study sought to contribute to the academic field, since the studies with the method application in the service sector are scarce and there is almost no study related to the hospital sector. Regarding the empirical consequences, the study provides alternatives to improve the decision-making process in a strategic sector of the hospital, an incipient field especially when it comes to the public sector.

In recent years, the application of this method in the health systems have increased. However, compared to other sectors, the use of this method and similar methods is limited, mainly due to the lack of knowledge of health authorities regarding these methods.

The findings of this study provided managers with valuable insights into the dimensions that reflect decision making when choosing the best supplier at a university hospital, with criteria such as price, acceptance, cycle time and delivery compliance selected by a team of specialists from the pharmacy supplies purchasing department at the university hospital. By knowing these criteria, hospitals can increase their quality of service by selecting the best supply options for medical and hospital supplies, providing better service to patients.

It is worth mentioning that the proposed decision-making model was evaluated by the FAHP. Other methods that can be used to assess the quality of the health service. One of these methods is the analytical network process (ANP) of Saaty (2008) that can be used in a fuzzy environment. 


\section{REFERENCES}

ALVES, J. R. X.; ALVES, J. M. (2015) Definição de localidade para instalação industrial com o apoio do método de análise hierárquica (AHP). Produção, v. 25, n. 1, p. 13-26. Available from<http://www.scielo.br/scielo.php?script=sci_arttext\&pid=S010365132015000100013\&lng=en\&nrm=iso>. Access: 12 Feb. 2018.

AMID, A.; GHODSYPOUR, S. H.; O’BRIEN, C. (2011) A weighted max-min model for fuzzy multi-objective supplier selection in a supply chain. International Journal of Production Economics, v. 131, n. 1, p. 139-145.

AZEVEDO, C. S. (1993) Gerência hospitalar: a visão dos diretores de hospitais públicos do município do Rio de Janeiro. Dissertation. Instituto de Medicina Social, Universidade Federal do Rio Janeiro, Rio de Janeiro.

BRANS, J. P.; MARESCHAL, B. (2005) Multiple Criteria Decision Analysis: State of the Art Surveys. New York, Springer

BÜYÜKÖZKAN, G.; ÇIFÇI, G.; GÜLERYÜZ, S. (2011) Strategic Analysis of Healthcare Service Quality Using Fuzzy AHP Methodology. Expert Systems with Applications, v. 38, n. 8, p. 9407-9424.

BRIOZO, R. A.; MUSETTI, M. A. (2015) Método multicritério de tomada de decisão: aplicação ao caso da localização espacial de uma Unidade de Pronto Atendimento - UPA 24 h. Gest. Prod., v. 22, n. 4, p. 805-819.

CHANG, D. Y. (1996) Applications of the extent analysis method on fuzzy AHP. European Journal of Operational Research, v. 95, n. 3, p. 649-655.

CHATTERJEE, D.; MUKHERJEE, B. (2013) Potential hospital location selection using fuzzy-ahp: an empirical study in rural India. International Journal of Innovative Technology and Research, v. 1, n. 4, p. 304-14.

CORSI, A (2017) Aplicação da Métodologia Analytic Hierarchy Process para a Seleção de Fornecedores em um Industria de Confecção. Trabalho De Conclusão de Curso (Graduação em Engenharia de Produção) - Universidade Estadual de Maringá, Curso de Engenharia de Produção, Centro de Tecnologia, Maringá.

DE CARLOS, F. M. (2016) Implementação da metodologia fuzzy AHP para tomada de decisão da localização de armazéns de trigo no Paraná. Trabalho de Conclusão de Curso (Graduação em Engenharia de Produção) - Universidade Estadual de Maringá, Curso de Engenharia de Produção, Centro de Tecnologia, Maringá.

FURTADO, G. A. P. (2005) Critérios de seleção de fornecedores para relacionamentos de parceria: um estudo em empresas de grande porte. Dissertação de Mestrado, Faculdade de Economia, Administração e Contabilidade, Universidade de São Paulo, São Paulo.

GOMES, L. F. A. M.; GOMES, C. F. S. (2012) Tomada de decisão gerencial: enfoque multicritério. 4. ed. São Paulo: Atlas.

GONZÁLEZ-BENITO, J. (2007) A theory of purchasing's contribution to business performance. Journal of Operations Management, v. 25, n. 4, p. 901-917. 
GURGEL JUNIOR, G. D.; VIEIRA, M. M. F. (2002) Qualidade total e administração hospitalar: explorando disjunções conceituais. Ciênc. Saúde coletiva, São Paulo, v. 7, n. 2, p. 325-334.

HILLIER, F. S.; LIEBERMAN, G. J. (2013) Introdução à pesquisa operacional. 9. ed. Porto Alegre: AMGH.

KAHRAMAN, C. (2008) Fuzzy multicriteria decision making: theory and applications with recent developments. Turkey: Springer Science.

KEISLER, J. (2004) Value of Information in Portfolio Decision Analysis. Decision Analysis, v. 1, n. 3, p. 177-189.

LEENDERS, M. R. (1997) Purchasing and supply management. $11^{\text {th }}$ ed. Boston: Irwin/McGraw-Hill.

LIBERATORE, M. J.; NYDICK, R. L. (2008) The analytic hierarchy process in medical and health care decision making: a literature review. European Journal of Operational

Research, v. 189, n. 1, p. 194-207.

LIMA JUNIOR, F. R. (2013) Comparação entre os métodos Fuzzy TOPSIS e Fuzzy AHP no apoio à tomada de decisão para seleção de fornecedores. 2013. $150 \mathrm{f}$. Dissertação (Mestrado) - Curso de Engenharia de Produção, Universidade de São Paulo, São Carlos.

LIN, C-T; WU, C-R; CHEN, H-C. (2008) The study of construct key success factors for the Taiwanese hospitals of location selection by using the fuzzy AHP and sensitivity analysis. International Journal of Information and Management Sciences, v. 19, n. 1, p. 175-200.

LINHARES, C. G.; GUSSEN, C. T. G.; RIBAS, J. R. (2012) O método FUZZY AHP aplicado à análise de riscos de usinas hidrelétricas em fase de construção. Congresso Latino-Iberoamericano. Rio de Janeiro.

MALIK, N. A. (1998) Qualidade na gestão local de serviços e ações de saúde. In Série Saúde \& Cidadania. Ed. Fundação Petrópolis, São Paulo.

MEIRELLES, D. S. (2006) Características das firmas e dos setores de serviço segundo o Processo de trabalho: uma análise exploratória multivariada. 2006. XXXIV Encontro Nacional de Economia. Available from<http://www.anpec.org.br/encontro2006/artigos/A06A174.pdf> . Access: 11 abril 2018.

OSIRO, L. (2013) Uso da lógica fuzzy para avaliação e desenvolvimento de fornecedores baseado em modelos de portfólio. 2013. $243 \mathrm{f}$. Tese (Doutorado) - Programa de Pós-Graduação em Engenharia de Produção, Universidade de São Paulo, São Carlos, 2013. Available from <http://www.teses.usp.br/teses/disponiveis/18/18156/tde-27032013092914/publico/LauroOsiroDEFINITIVO.pdf> Access: 23 de março de 2017.

PERUCIA, A.; BALESTRIN, A.; VERSCHOORE, J. (2011) Coordenação das atividades produtivas na indústria brasileira de jogos eletrônicos: hierarquia, mercado ou aliança? Produção, v. 21, n. 1, p.64-75.

SAATY, T. L. (2008) Decision making with the analytic hierarchy process. International Journal of Services Sciences, v. 1, n. 1, p. 83-98.

SAMED, M. M. A.; GONÇALVES, M. B.; CURSI, J. E. S. (2014) Logística humanitária: uma abordagem AHP-FUZZY para a localização de centrais temporárias. In: Congreso panamericano de ingeniería de tránsito, transporte y logística, XVIII, 2014, Santander.

Anais.... Santander, PANAM, 2014. 
SCHMIDT, M. A. R.; BARBOSA, R. B. (2016) Uso de Redes Neurais Artificiais na Ponderação Inicial da Técnica AHP em Análises de Vulnerabilidade de Bacias Hidrográficas. Boletim de Ciências Geodésicas. On-line version, v. 22, n. 3, p. 511-525.

SHAW, I. S.; SIMÕES, M. G. (1999) Controle e Modelagem Fuzzy. 1º. ed. São Paulo: Edgard Blücher Ltda.

SILVA, E. L.; MENEZES, E. M. (2005) Metodologia da Pesquisa e Elaboração de Dissertação. 4. ed. Florianópolis: UFSC.

SOLTANI, A.; MARANDI, I. Z. (2011) Hospital site selection using two-stage fuzzy multicriteria decision making process. Journal of Urban and Environmental Engineering, v. 5, n.1, p.

SOUZA, D. F.; VIEIRA, T.; LOPES, M. R. C. M.; FRANCISCO, R. (2010) Aplicação do método ahp-fuzzy. Encontro Regional de Estudantes de Matemática do Sul (EREMATSUL). Guarapuava.

TAHA, H. A. (2003) Operations research: an introduction. 7. ed. Upper Saddle River: Prentice Hall. 